\title{
Agrarian and Land Reforms in Rwanda: Situation and Perspectives
}

\author{
Mireille Mizero ${ }^{1}$, Antoine Karangwa ${ }^{2}$, Philippe Burny ${ }^{1}$, Baudouin Michel ${ }^{1}$, Philippe Lebailly ${ }^{1}$ \\ ${ }^{1}$ Département d'Economie et du Développement Rural, Gembloux Agro-Bio Tech, Université de Liège, \\ Belgium \\ ${ }^{2}$ Department of Rural Development and Agricultural Economics, School of Agriculture and Food Sciences, \\ University of Rwanda, Rwanda
}

\begin{abstract}
Rwanda is a landlocked country of Eastern Africa with $26,338 \mathrm{~km}^{2}$. The total arable land in Rwanda is more or less than 1.8 million ha and Rwanda has the highest population density in Africa. A series of policy reforms and agrarian strategic plan have been elaborated to transform the economy now oriented towards subsistence agriculture into a knowledge-based service and market-oriented economy. The research question is who has the right to land ownership for its rational use? The purpose of this article is to contribute to land sharing prospects between agricultural operators and investors in Rwanda for the optimisation of land access in the rural areas. This work is the result of deep literature review related to the situation of land issue prevailing from pre-colonial period to the recent 2004 land policy reforms in Rwanda. Crucial challenges before the beginning of the effective agrarian evolution are widely discussed. Agrarian perspectives show that the foreignization of agrarian reforms put Rwandan peasants in uncomfortable position. The changes in land use and tenure in Rwanda have been stimulated by both outside influence and inside adversary forces. The real land reform policy consists in specialization and exploitation of large-scale farms subsequent to land consolidation of small plots registered by individuals whose property certificates are preserved. Meanwhile, the required registration of land holdings does not entitle the land to definitive appropriation but it only provides the rights of use if rational exploitation is guaranteed. Such a rational system may result in expropriation for the inefficient producers. This article emphasize that in the case of Rwanda were population growth rate is high, the redistribution of land has its limits. The land consolidation should not be a rule either. Any agrarian reform must find a point of balance. This equilibrium consists in reducing the pressure on the property assets and promoting rural entrepreneurship. Agriculture program may improve and diversify the mode of land access and improved input acquisition to feed a growing population whereas non-agriculture population is gradually increasing. It has been found that farmers operating in co-operatives are more secure and have advantage for land access than individual farmers.
\end{abstract}

\section{Keywords}

Land access, agrarian perspectives, land reforms, foreignization, Rwanda.

Mizero, M., Karangwa, A., Burny, P., Michel, B. and Lebailly, P. (2018) "Agrarian and Land Reforms in Rwanda: Situation and Perspectives", AGRIS on-line Papers in Economics and Informatics, Vol. 10, No. 3, pp. 79-92. ISSN 1804-1930. DOI 10.7160/aol.2018.100307.

\section{Introduction}

Rwanda is one of the landlocked countries of sub-Saharan Africa. It covers an area of $26,338 \mathrm{~km}^{2}$. According to the results of the general population and housing census, held from 16th to30th August 2002, the population density calculated on an occupied area of $25,314 \mathrm{~km}^{2}$ was evaluated at an average of 322 inhabitants $/ \mathrm{km}^{2}$. There were 283 inhabitants $/ \mathrm{km}^{2}$ in 1991, date of the last census before the 1994 genocide (Ministry of Finance and Economic Planning, National Census Commission, 2003). "The population density in 2012 was 415 inhabitants per square kilometres. Compared to neighbouring countries: Burundi(333), Uganda (173) or Kenya (73), Rwanda is the highest densely populated county in the region. It was only 183 persons per sq. $\mathrm{km}$ in 1978, and 321 in 2002 " (National Institute of Statistics of Rwanda (NISR), Ministry of Finance and Economic Planning, 2012). The population growth is almost $3 \%$ annually and income per capita increase to $4.67 \%$ in contrast with $2.65 \%$ in Sub-Saharan Africa between 2000 
and 2010 (WDI; 2012 cited by Klasen and Reimers, 2014). A recent report by the International Monetary Fund (2016) has recognized that almost half of the Sub-Saharan African countries, including Rwanda, have experienced declining in their economy. The raw material commodity prices decreasing on the international market is the main cause (International Monetary Fund, 2016). The downward trends of the raw material prices on the international market are likely to extend over a long period, according to the cited International Monetary Fund report.

The International Monetary Fund assumes that constant economic growth in some Sub-Saharan countries, over the last decade, was due to both strong economic reforms, rigorous domestic policies and a favourable external environment. International Monetary Fund injunction is quite clear. It recommends to those countries with declining economies to make deep revision of their internal economic policies in this thorough terms "changement de cap" in order to deal with the deterioration of the external economic environment. The inclusion in a market-led economy and improvement of the business environment are on the agenda of reforms of legal frameworks and economic policies to avoid emergency adjustments according to the IMF (2016). It is clear that the Rwandan government is convinced that solutions to the socio-economic challenges the country is tackle cannot be solved only at the local level neither is the country viable on its own (Van Hoyweghen, 1999). Therefore, he cannot claim self-sufficiency without opening himself to the global market and carefully transform his economic model. However, according to Ansoms (2009), the risk of the marginalization of peasant is high with an agrarian reform policy that masks the social realities of rural Rwanda.

The agricultural sector is the priority in regard to his important role in Rwandan economy (Karangwa, 2008, Musabanganji et al., 2016). The current mode of organization of agriculture sector, which has been traditional for many decades, has low levels of productivity (Karangwa, 2008). However, the transformation of agricultural production systems and the demand-driven agriculture should improve the performance of farms (Republic of Rwanda, Minister of Natural Resources, 2006; Karangwa, 2008). The country has embarked on a strategy of intensification of strategic food crops: rice, maize, beans, potatoes and wheat as well as the traditional export crops such as tea, coffee, pyrethrum (Republic of Rwanda, Minister of Natural Resources, 2006). Rwanda is engaged on the efficient use of land and water. Therefore, agriculture sector is moving from subsistence model to the market oriented one. Rwanda intends to reduce the dependence of the population on agriculture as the only source of income through the consolidation of other sectors, namely industry and services (Republic of Rwanda, Minister of Natural Resources, 2006). Thus, the government needs a new agriculture strategic plan and land reform framework to boost agriculture performance in a sustainable way (Musabanganji et al., 2016).

Indeed, the post-genocide government has committed to market-led agrarian and land systems opposed to State-led land reforms (Nkusi, 2000). The Strategic Plan for the Transformation of Agriculture in Rwanda (PSTA) is based on four pillars summarized as follows: The transition from a subsistence agricultural economy to a market-led economy, the intensification and gradual modernization of the agricultural sector, the redistribution of roles and responsibilities among all stakeholders in accordance to the new agricultural policy, State withdrawal from several sectors, decentralization and new working methods. The Minister of Agriculture and Livestock adopted the program approach (Republic of Rwanda, Ministry of Agriculture and Livestock, 2004).

The Republic of Rwanda and the Minister of Natural Resources (2006) are convinced that high density of the population is the main cause of land scarcity. According to the government of Rwanda, the critical situation of land insufficiency is worsening by the fact that most farmers practice mainly rain fed agriculture. Soil fertility has deteriorated as a result of the demographic pressure on land, while the use of organic and non-organic inputs remains very low. Other serious constraints are that many lands in Rwanda are at high risk of erosion due to the high land dominant topography. The government considers that the inadequate management of natural capital and the use of traditional technologies have led to soil degradation (Republic of Rwanda, Minister of Natural Resources, 2006).

Some concerns arise when policymakers intend to transfer responsibilities to other stakeholders and let the global market become the engine of local agrarian destiny. How is it possible to conciliate both human needs and land sharing in a pragmatic way of rational agrarian perspectives? Who has the right to own land for a rational use to compensate the gap of production of those who could not access to individual land property? The purpose of this article is to contribute to agricultural land sharing 
prospects in Rwanda. The first and the $2^{\text {nd }}$ section review the origin of agrarian reforms in general and the evolution of the pattern of land reform adopted in Rwanda. The methodology in detail is presented in the $2^{\text {nd }}$ chapter. Main results are discussed in the 3rd chapter. The 4th and last chapter covers the major conclusion and agrarian perspectives in Rwanda.

\section{Concept of agrarian reforms and individual property}

According to Dufumier (2004), the general definition of agrarian reform consists in the State intervention of redistributing land accumulated by large landowners to landless peasants and small scale farmers. Agrarian reforms should normally result in an equal distribution of land. To be effective, agrarian reforms must be followed by a number of accompanying measures to make available other agricultural inputs such as water, livestock, a minimum of efficient equipment, credits, improved infrastructures and trustworthy services. Even that definition is very clear and correct politically as well as morally justified, it is not as easy as it seems to be when the big landholders are asked or imposed to share their farmland to the landless. Many examples can be assessed in Africa and elsewhere in the world. Without an exhaustive record, the case of South Africa post-Apartheid, the recent Zimbabwean and in Mozambique, land reforms has shown that it is not easy to proceed by expropriation of big farmers who have developed strong trajectories to safeguard their assets through political lobbies and stable socio-economic positions (Compagnon, 2003; Dufumier, 2004; Cousins, 2007; Fairbern, 2013).

The modern concept of agrarian reform would have been initiated by the agrarian transformation in the Scandinavian countries, probably in Danmark in the late 1700s (Herrera et al., 1997). Based on ideas emerging in European countries such as England, France and Germany, the Counts of Bernstorff and Reventlow, reformists, have instigated a program of consolidation of the fields holds by their peasants. They introduced new technologies and facilitated the sale of land to their peasants as well as their new status of ownership protection (Skovgaard, 1950 cited by Herrera et al., 1997). Securing landowner status is necessary but not sufficient. Indeed, in the agricultural sector, property is good in itself, but it is not enough. According to Lenoir (1984), when the farms areas are at least few hectares, the debt necessary for their equipment is not profitable, and the supervision of the peasants by technicians is inefficient. The disorder in land management of these parcels leads to their impoverishment (Lenoir, 1984). Agricultural modernization is facilitated by largescale production facilities applied on large farms, at least 50 ha where production techniques based on advances in science and technology are used to produce for export the surplus. Private property and land consolidation is central to this view of modern agriculture (Burger, 2001).

Article 3 of the 2005 Organic Land Law in Rwanda stipulates that land is the common property of all Rwandans but only the State has an eminent right to the agreement of occupation rights. The certificate of ownership gain by a small operator is nothing else than a right of occupation. Nkusi (2000) is clear when he precise that the registration of individual properties will facilitate transfer or acquisition procedures, especially because most Family farms are under the threshold of profitability. The absence of registration is a barrier of control over the exchange and transfer processes and the consolidation of farms according to the author (Nkusi, 2000).

Every recognized landowner obtains, outside the public and private domain of the State, an emphyteutic lease contract ranging from 3 to 99 years as envisaged by the articles 5, 24 and sections 2 and 3 of the cited Organic land law. According to the article 20 of the same Organic Land Law, it is forbidden to divide rural lands for agriculture and pasture with an area less than 1 ha. Those with an area inferior to 5 ha can only be divided after authorization by the local land commission. The means of rational exploitation of a consolidated land become more significant (Nkusi, 2000). Nkusi (2000) supports that land owner is not really the technical operator. He distinguishes land ownership and land use.

All marsh lands automatically belong to the State. They cannot be definitely transferred to individuals or acquired in private manner under the pretext of having occupied the marsh lands for long time (art. 29 of the Organic Law 08/2005, 14/07/2005 governing land tenure in Rwanda). In addition, the landowner is required to rationally and continuously exploit his property. Like this coercive version of agrarian reforms is based on expropriation with or without compensation of former large landowners. It has inspired many communist and its variant socialist countries (Herrera et al., 1997). 
Indeed, the Russian revolution of 1917 and various socialist and populist regimes between the first and the Second World War converted the ideology of agrarian reform in the Western World, from a liberal economic process to a model of equity in rural areas led by the state to redistribute land (Herrera et al., 1997). The author noted that, in fact, it was the reason why a class of conservative landowners did not want to participate in land reform. Most land reforms in Latin America, Asia and the Near East have been derived from this coercive model. Therefore, from the foundation of FAO in 1945, agrarian reform was considered as one of the main tools for rural transformation and agricultural development (Herrera et al., 1997, pp. 53-54). The coercive forms of obligatory fragmentation of large estates into small holdings for distribution to landless peasants by the State intervention are currently discouraged. In so-called "modern" agriculture, the transformation of land into a marketable commodity like other agricultural goods and products is becoming the trust model supported by international institutions and financial partners lead by FAO (Herrera et al., 1997).

\section{Evolution of land size in Rwanda}

The total arable land in Rwanda has increasing in time and in space but the individual land size has decreased. The farmland size is in average equal to 0.23 ha for the majority of agriculture operators and those who owned 10 ha of farmland are considered as large scale landholders (NISR, 2015) while in western countries, a large scale farmer can own several hundreds of ha. According to REMA (2009) the total arable land is about 1.4 million hectares which represented almost a half of the total surface area of the country. In the recent years, the cultivated area has exceeded 1.6 million ha and the recent seasonal agriculture survey revealed that the whole land covered by agriculture domain is equal to 1.8 million ha (NISR, 2015). The Republic of Rwanda precise that permanent pasture covers 0.47 million ha and someone can keep in mind that over 70 per cent of the country's total land surface is occupied by agricultural related activities (ROR 2008 cited in REMA, 2009). The topographic profile of Rwanda is dominated by hills and mountains. Then, the low land in Rwanda is limited to almost 165,000 ha of marshlands of which about $57 \%(93,754$ ha) have been cultivated. However, some 5,000 ha have been well managed and are ready to be cultivated (REMA, 2009). The Republic of Rwanda deplores the fact that a large part of the marshlands are exploited by peasants, whether or not they are in co-operatives, without prior studies have been carried out (ROR, 2008 cited in REMA, 2009).

\section{Criteria of rational use of the farm land}

Article 63 of the land law in Rwanda stipulates that: The conservation or continued rational exploitation of land shall be assessed according to its use in accordance with the master plan for the allocation, development and use of land. Rational use is also validated if agriculture operators and investors have adopted particular crops and techniques designed by the competent authorities. Continuity of exploitation is evaluated in relation of the duration of non usage that cannot exceed 3 years (Article 64). This article states that shall be accepted as conserved and exploited rationally, the land carrying crops or buildings, those carrying forests so as not to pollute the environment, those prepared for receiving seeds, those whose crops have just been harvested and setting aside for a period not exceeding 3 years, those which have just been harvested, as well as those of the pastures on which individuals graze the authorized animals, either individually or collectively or in organization enjoying a legal personality. Article 65 completes it to clarify the 5 criteria for assessing land considered as not conserved or rationally used:

- That not protected against erosion.

- That intended for agriculture but which is not covered by plantations or cultivation on at least half of its area.

- Land dedicated to grazing but which is not actually and regularly occupied by livestock grazing or not covered with fodder crops at least on half of its area.

- Land intended for any kind of construction but whose construction has not been completed within the deadlines set by the law.

- That intended for non-profit use but activities have not started before a maximum period of three years.

In the following pages, we describe how land reforms in Rwanda were not only a product of inside enterprise. They have been influenced by outside ideologies joint with inside rival forces.

\section{Rwandan agrarian reforms characteristics}

Nkusi (2000), consultant of CCOAIB (Conseil de concertation des organisations d'appui aux initiatives de base) advocates that the transfer of the rights of appropriation is necessary to allow the extension of the agricultural holdings. Transfer land facilitation aim the increasing 
of crop production must be in favour of the people who are fully responsible and masters of their rights and open to the economic objectives of the government. According to him, these paths allow to solve future land conflicts and prevent the country from experiencing social explosions like those in Zimbabwe. For the history of agrarian reform in Zimbabwe refer to the critical analysis did by Professor Daniel Compagnon at "Institut d'Etudes Politiques de Bordeau". Although it intended to expropriate the big farmers, land reforms in Zimbabwe are controversial. Instead of benefiting the peasants, it has rather contributed to land grabbing by former rebels close to Mugabe's government (Compagnon, 2003). Zimbabwean agrarian reforms are close to those operated during the first Republic of Rwanda regarding the violence against and killings of the big farmers they have prompt.

The post-genocide Rwandan approach is a quiet and gentle dispossession of landowners unable to achieve the objectives set by the land tenure reforms. The strategy of redistribution is oriented towards to the big investors to achieve the purpose of progress in land productivity. In this context, free consent in the purchase, lease or sale of exploitation rights are being facilitated by the authority (Nkusi, 2000). The pre-colonial land regime was based on agriculture and livestock integration. Nkusi (2000) depicted the "Ubukonde and Ibikingi" system as a dynamic and integrated system based on the customary rights. There were sporadic conflicts between agricultural and pastoral families for good grazing lands, transhumance areas and the control of quality sources of water. Land relations were based on the lack of restrictions of occupation of the territory. Agricultural and pastoral productions were linked with other professional trades such as handicraft. Maquet (1967) contested this description of land sharing harmony in traditional Rwanda. He has established a comparative model between the feudal patterns in the Middle Ages in Europe and the traditional Rwandan land system.

Nkusi (2000) estimate that ownership by the "Umukonde: large landowner" was not rational. Proprietor "Mukonde" easily had an area beyond 500 hectares with the possibility to establish several client families. Different armed groups have introduced a new form of political patronage on land in violation of the traditional land tenure. There were different customary land law in pre-colonial Rwanda related to pasture and culture rights (Maquet, 1967; André and Platteau, 1996; Nkusi, 2000). The more significant were:

- $\quad$ "Ubukonde": right of ownership of the family leader who has slashed the forest.

- "Ubugererwa": right of exploitation temporarily transferred to persons or families settled by the head of the «Mukonde» family.

- "Inkungu" is the customary right of local politicians to manage unclaimed or abandoned properties.

- "Intora": customary right established by the local politician to appropriate a field or to take a part of the land from the landholding of each client family living in his district. This land, considered as the counterpart of the chief duty, was crop-free but cleared.

- "Gukeba or Kugaba": to establish people in a grazing land or on uncultivated land by the chief of the clan.

- "gikingi": grazing right recognized for herders' families and integrated into customary pastoral law.

- "Igisigati and Igikorera": customary law of free grazing on harvested agricultural areas.

- "Ubuhake": usufruct right on cow in exchange of security guaranteed by a powerful owner to his client who continues to provide other services to the patron (Maquet, 1967).

The extension of the territory by conquest wars was still valid as a strategy for farmland and pastures extension. Colonization stopped this expansionist approach of the territory and introduced a dualistic land tenure system. The Germans have not changed the customary law of traditional Rwanda. They recognized the king's sovereignty over the land. The land purchased by the Catholic and Protestant missions was based on the delivery of gifts, not monetary compensation (Nkusi, 2000). The supremacy of the written law to the customary law was introduced by the Belgians after the First World War. The 1926 reform organizes a cohesive territory and removes the rights of customary chiefs to dispose of land outside their districts. Colonization introduced the occupation certificate on land. But people should not be dispossessed of the land wherever they grow crops. Unused and vacant lands returned to the hands of the state. Verwimp (2011) revealed that the explosion of socio-political conflicts in 1959 showed the limits of the land tenure system in Rwanda. The violent dispossession of the pastoral peasants has taken an ethnic aspect. This crisis 
also reversed the balance of political power after the independence in the 1960s. The land and livestock properties of the Tutsi refugees were redistributed to Hutu residents by the State dominated by Hutu leaders (Verwimp, 2011).

The "Ibikingi" pastoral system was abolished and the "Bagererwa": landless peasants obtained vacant land as individual properties. According to Nkusi (2000), the decree of 1960 aimed to protecting the interests of the settled people and guaranteeing them security of tenure. The 1976 decree-law practically expropriates the Rwandan population and attests the State as the owner of the land. The populations continued their occupation as usual and did not change their habits in matters of land acquisition or transfer. The State did not take any measures to harmonize agricultural land ownership based to the written law. The result of that reform is a binary system of land tenure. The first derived from the roman law of property (Maquet, 1967) is secure and inalienable and other customary rights become fragile (Nkusi, 2000). The new land tenure strategy after withdrawal the former occupants showed its limits during the post-independence period.

The 1970s and 1980s were characterized by a period of agricultural prosperity broken down by the demographic pressure (Amelot, 1997). During the 1990s, the pressure on agricultural space was a sad reality. The government was lacking arguments and durable solutions to deal with the tension generated by land scarcity challenge. Internal migrations became absolutely impossible for the extension of landholdings. The average family farm decreased from 2 ha in 1960 to 1.2 ha in the mid-1980s (Nkusi, 2000), represent $40 \%$ loss of the size of family farms in one generation. The justification for keeping Rwandan refugees in exile outlook by the former President Habyarimana was no longer a solution to the problem of land scarcity. Population growth eventually made unsustainable all attempts to manage the land. The land issue in Rwanda is endorsed by several authors to the "Malthusian trap" (André and Platteau, 1996). The 1990 war led by the 1959 refugees has challenged the political system unable to solve the old dispute related to land access and control. The new wave of refugees from 1996 after the genocide against Tutsi in 1994 created complicated situation about land sharing. There was another vicious cycle of dispossession and illegal appropriation. The new regime ruling after the historic genocide of 1994 manifest the beginning of a new era of land governance based on the principles of liberalization of the land market. However, the process is overseen by the government.

\section{Materials and methods}

The methodology consists in a multidisciplinary approach. Bibliographic review of the relevant scientific literature was undertaken by using the following key words: Rwanda, land access, agrarian perspectives, land reforms, foreignization, and peasant. Reports from the national and international institutions have been consulted. Moreover, an analysis of the official discourses was done to capture the importance of the land issue in the public opinion. The methodological approach did not neglect the cultural aspects. Despite the generalization of the school system for education, Rwandan culture is both oral and written. The local language songs broadcast on radio, online videos are rich in information that few researchers are interested in socioeconomic studies. The history of the latest genocide in Rwanda has shown that radio is an important tool for mobilizing and relaying messages designed by the authorities to reach a larger audience. Even if advanced technologies in information and communication have been improved in Rwanda, the reading culture is not common. The expression of emotions or claims is usually conveyed by lyric songs. Through musical expression, there is a way to decode approvals or disapprovals of policies or practices, concerns and messages that the authors want to share with a wide audience as quick as possible. Videos posted on YouTube by opposition media were visualized.

In addition, the analysis of agrarian perspectives to follow up land policy change and agro-economic strategies of land sharing in Rwanda requires comprehensive tools that are sometimes need to be developed. Thus, the model below (Figure 1), allows to demonstrate the appreciation of agricultural land in relation with growing population. The model illustrate what is happen when people decide to keep their farm as common land property or to share and grouping their owned land or to share without pooling together their individual plots. Further on, the dispossession risk from smallholdings to constitute large farms as required by the 2004 agricultural land policy is closely examined. The constitutional hypothesis agree that land is a common good to all Rwandan, agricultural land belongs to the whole population in the country like the family land belongs to all its members. The later could share equally the farm 


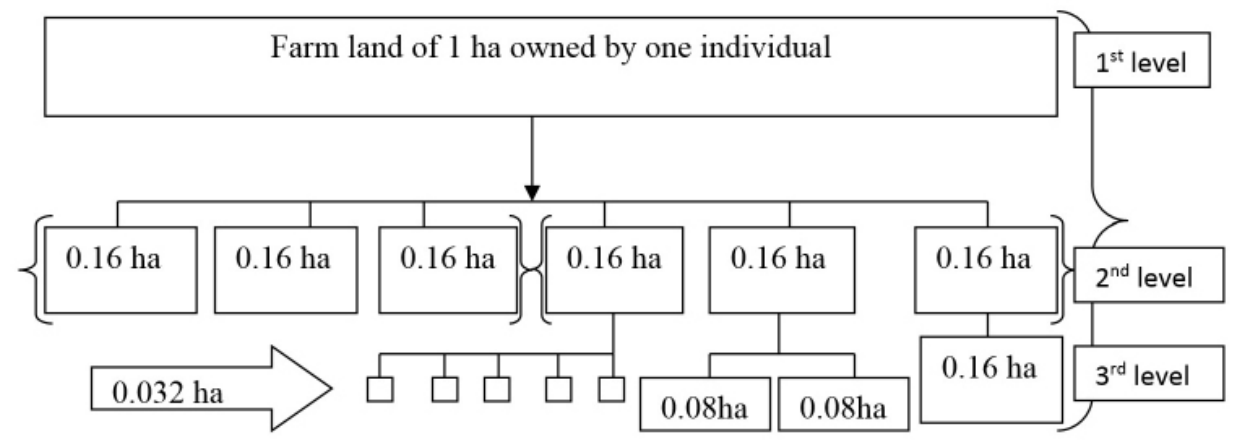

Source: Established by the author, modified from Ndayishimiye (2005)

Figure 1:.Land sharing limits in the context of land scarcity.

without exclusion. Each landowner will sooner or later do the same for his children in the future. Even before the land sharing occurs, each member of the household is supposed to own his part of the land inheritance. The diagram above (Figure 1) shows for example a case in which a farm land of one ha belongs to 1 individual at time $\mathrm{t}$ and has been shared between fifteen descendants after 2 generations. Even if its members decide to concentrate their individual parcels it is not exceeding 1 ha both. In the country or within families, agriculture and non-agriculture population interfere in land demand. Land access becomes complicated if everybody needs individual property. It was up to land owners to choose if they share or consolidate their holdings. But now, the land law in Rwanda is clear. A property of one ha cannot be fragmented. From one ha, six individuals possess $1 / 6$ ha each at the second level. It'll be $1 / 30$ ha each when 5 individuals are sharing 0.16 ha at the third level. When there are 2 stakeholders on the third level, they'll get $1 / 12$ ha each. If the owner to the second level has no descendant he'll keep his $1 / 6$ ha after free generations. At the opposite, if three individuals decide to concentrate their plots on the $2^{\text {nd }}$ level they have a collective land of 0.48 ha. When all the 15 stakeholders from this family decide to pool their plots together, they have access to 1 ha. Otherwise, their marginal individual property equals to 0.06 ha. In this great fragmentation, some members of the family or some people in the country could search for other way of land access rather land ownership. Hereafter, their marginal individual property is under the minimum of cost-effectiveness.

\section{Results and discussion}

1. Analysis of the President Paul Kagames' speech on the land issue

Access to land is a high sensitive issue in Rwanda.
When he answered the questions of the local elected representatives during the meeting held in Kigali from $28^{\text {th }}$ to $30^{\text {th }}$ March 2018, His Excellency Paul Kagame, President of Rwanda said that the issue of access to land in Rwanda is a political question. Thus, it does not fall under the courts of justice. He told the audience that if that battle is to begin again, they are ready to fight. He insists that there is no way to continue to revisit this issue. Addressing this issue judicially would lead to complex question that lawyers and the Ministry of Justice cannot resolve. This debate must be closed, he ordered. He said that they must stop "Akajagari", means the disorder. He added that whoever wants to deal with this complicated question should first of all ask him the question of why the Rwanda Patriotic Front was founded. How did he came to power? This is not a question of the courts of justice, he concluded. He asked the assembly if they want to continue to revise everything.

Once the Minister of justice reply to the President of the Republic, he recognized that the land issue in Rwanda is a national concern. It concerns almost the entire country according to him. The issue was addressed during the Harusha peace negotiations between the former rebellion represented by current President Paul Kagame and the government of the former President of Rwanda Juvenal Habyarimana. In his response to the President's questions, he recognized that local administrative had debated this question, three days before. When, they held a retreat in Rubavu district, local representatives agreed to find out the way it should be closed. They have engaged to stop haunting the President's mind when he hears people claims every time in Nyaruguru, Rubavu, Karongyi, in the Eastern Region and so on. The Minister of justice remembered the audience that the issue of land sharing, the right to property and the land law reforms has been widely discussed, since Harusha. Long-time refugee has the right to be relocated but he must not recover his former property. 
His Excellency Paul Kagame was direct and intransigent in his reaction to the response given by the Minister of Justice during the meeting. According to President Paul Kagame, the big question is that if they turned that issue into a concept of jurisprudence, they may open up a problem they'll never overcome. He added that it is no longer a question for debate, because it would take another 5 years, 10 years without verdict.

2. Analysis of the speech of the President of Alliance for Green Revolution in Africa

When the issue of access to land remains complex and unresolved in Rwanda, there is also the question of integration and access to the market of small and middle enterprises. Mrs Agnes Kalibata, Former Minister of Agriculture and Livestock in Rwanda, has becoming the President of AGRA (Alliance for Green Revolution in Africa). Lately, she has been awarded for the Honoris Causa Prize in March 2018 by the "Université de Liège". In her speech, she regretted that the requirements of major financial institutions were incompatible with the operational conditions of small and medium-sized agricultural enterprises.

"The harsh truth is, if an investor expects that their investment will only go to the 5 or 10 million Euros type of businesses, and then they are not really serious about investing in growing African agriculture markets. Such investments will have minimal impact at scale [...]. Additionally, agriculture SMEs face some of the greatest risk which they have no capacity to absorb. This includes the foreign exchange risk. As they deal in food crops that are traded in local currency, they cannot borrow in foreign currency. They are also exposed to political risks. In most African countries, governments, for example, impose export bans for political reasons. This is done without regard for private agri-businesses which suffer as they can no longer access regional markets" (Kalibata, 2018).

3. Foreigner investors and elites power in business

On Sunday, 22 ${ }^{\text {nd }}$ January 2018, 12 GMT, Radio Itahuka, a medium of Rwandan citizens based in Washington DC broadcasts on Short waves 19M $15420 \mathrm{KHz}$. Major Jean Marie Micombero and Robert Mukombozi, activists in the opposition living in Belgium were interviewed. The journalist Serges Ndayizeye asked them to comment the doing business framework in Rwanda. They said that the Rwandan economy much more benefits to foreigners than to natives. Ansoms (2013) reported two cases of land grabbing in swampland by foreigner investors facilitated by local authorities in detriment of peasant's livelihoods. In the other hand, the case below reported in a video posted on YouTube by the Natural resources authority (2016) show a ceremony of land sharing in Rubavu district where large land owner has been expropriated in favour of small landholders.

\section{Large Landholdings: counterbalanced land sharing}

The land sharing ceremony was supervised by representatives of the Rwanda Natural Resources Authority (RNRA, 2016): "Ugusaranganya ubutaka: land sharing" in the North-Western Region of Rwanda, Rubavu District, Mudende Cell, Mirindi Sector. Matayo Ngirira, a large landowner has died but he was represented by his brother Michel Hategekimana. The later gave 22 ha of 50 ha of his land property. The land has been shared between 68 neighbouring families. Each of those 68 Rwandan families returned from Congo was given by the Rwanda natural resource authority an average small plot of 0.32 ha with a certificate of ownership. The former owner apparently rejoices for the outcome of this land dispute after 22 years of the conflict.

The lesson learned is that the way land is shared looks like unfair but reasonable. Smallholders with empty hands get small plots of land. On the other hand, the big landowner without having to lose all of his property, he remains with the big part of the cake. By the way, it had been demonstrate that there is a strong inverse relationship of land size and the productivity in Rwanda (Ansoms et al., 2008; Ali and Deininger, 2015). One more consideration is that those who get exploitation rights have the obligation of results. But they cannot guarantee to fulfil what authorities asked them to achieve if they are not supported by a coherent institutional and financial framework. The land system design in Rwanda is a mixture of small private properties in majority for survival livelihoods owned by those called "agriculture operators" and large private holdings for investment opportunities owned by those called "large scale farmers". The later are "the person, institution or cooperatives growing crops on minimum 10 ha or raising minimum 70 cattle, 350 goats or sheep, 140 pigs, 1,500 chicken or managing 50 bee hives" (Republic of Rwanda, National institute of statistics of Rwanda, 2016). 
5. Low value of the labor force disadvantages access to land for peasant

Ansoms (2013) qualifies as "large-scale land deals" the phenomenon where family farmers in African countries are facing hard competition with big investors both foreigners and local elites facilitated by liberalization policies on agricultural and land markets. Family farming is now forced to engage in agro-business so as not to be out of the market, where imperfect competition often prevails. The diagnosis of the agriculture labor force value shows that it is mainly based on poorly paid peasant (Ansoms, 2013). In 2002, the productivity of land and labor assessed by the Rwandan Minister of agriculture and livestock was $\$ 409 /$ ha/year, or $\$ 1.12 / \mathrm{ha} /$ day. The daily wage of an agricultural labor force is estimated between $\$ 0.91$ and \$1.36/day. Labor fees below \$1.99/day according to the World Bank estimation are not enough (Republic of Rwanda, Ministry of Agriculture and Livestock, 2004).

It is insufficient compared to the high cost of living in Rwanda (Ansoms, 2013). The average farmed area per farm household is about 0.75 ha and $11.5 \%$ of rural households do not own land (Republic of Rwanda, Ministry of Agriculture and Livestock, 2004). In the Nyabarongo swamp, daily wage of 7 hours of agriculture labor force is paid 400Frw/day equivalent to $0.5 €$ /day sometimes fewer (Ansoms, 2013). The payment is regularised at the end of the month related to the number of days worked. Meanwhile, selling farm labor force is a way to earn some cash immediately to meet the urgent needs. This inadequate salary does not attract the peasants to work in so-called "modern" farms. According to Ansoms (2013), they prefer to work on their fields than to engage in largescale sugar cane plantations hold by a foreigner investor. The situation is likely to generate "a rural proletariat" and transform poor peasants into poorly paid labor force (Ansoms, 2013). This situation does not improve access to land. Human Rights Watch (2001) cited by Leegwater (2015), reports that « the government intended to create modern, larger-scale agricultural production methods. Distancing peasants from their fields, a deputy reasoned, would cut their emotional attachment to the land and make them treat it more as an economic good valued only in terms of its productive capacity» Leegwater (2015).

6. Redistribution and concentration of land guide: hybrid reforms

The characterization of agrarian reforms in Rwanda is not easy. They represent ambiguities or very striking contradictions. This shows, on the one hand, that the government is torn between market-led and state-led agrarian reforms. The application of the donor's obligations who advocate the liberalization of the economy is not matching with the reconciliation of the Rwandan people. The foreignization is not only the facts of foreigners facilitated by local elites involved in land grab (Fairbairn, 2013). Whenever governments are influenced by outside prototype of land and agrarian governance can be consider as land policy foreignization. On the one hand, the land policy gives the impression of highlighting the interest of the peasantry by questioning the big landowners. Land is taken over by the authorities from the large landowners and they are redistributed to the landless poor returnees. This decision is a minimum of social justice. The landholder obtains individual property certificate. At the same time, they are advised that these certificates of ownership are not considered as definitely acquired. Rational use of granted land is an obligation and not an individual farm management decision.

Once the land is obtained, it must be used in the respect of the instructions fixed by the administration who is the guarantor of the implementation of the agricultural policy (Kathiresan, 2012). In Rwanda, access to land is possible through several means of temporary or permanent appropriation such as inheritance, rent, gift or purchase. The government seeks to facilitate access to land and the rational use of agricultural resources through the liberalization of the land market. For instance, a hybrid land sharing scheme is being operate where redistribution of land coexists with the collectivization of redistributed lands. Kathiresan (2012) mentioned in his report that joining the land consolidation program is voluntary. However, he added that land consolidation is a condition for access to other services provided by the Crop Intensification Program (CIP). This proves that choices are limited for peasants. Although, making a choice not to participate in the agricultural intensification program is free, the opposite is a choice that hinders access to inputs and financing.

Pooling individual land properties in collective large bloc is therefore not voluntary but conditional. Land holders are involved in large scale economy. "Consolidated use of lands allows farmers to benefit from the various services under the Crop Intensification Program such as inputs (improved seeds, fertilizers), proximity extension services, 
post harvest handling and storage facilities, irrigation and mechanization provided by publicprivate stakeholders" (Khatiresan, 2012).

\section{Conclusion}

The land reforms in Rwanda initiated in 2004 are based on the systematic registration of properties so that the landholder has an individual status of landowner. They were carried out under land redistribution program to former Tutsi refugees flee out in 1959 and other landless peasants returned after 1994 Rwandan Tutsi genocide. Land consolidation has been ordered as a way of sharing land to try to increase the access of many peasants "abahinzi" to the land. Farmers who pool together their plots are considered as legal shareholders who retain their individual property rights over the consolidated large-scale land. Formerly, the expected production on consolidated land is likely to increase. However, this is a simplified way to address the issue of farmers' access to land and increased productivity. Even in the land consolidation perspective, one hectare shared between 15 stakeholders remains inelastic. Landlessness prediction could decrease if the marginal individual property increases. In these perspectives, population growth is decreasing or agriculture population is declining over time.

On the structural level, traditional Rwandan agriculture is rooted in logic of recognition of the food function of agriculture to meet the nutritional needs of the family. On the other hand, it is economically justified for the farmer himself to cultivate the foodstuffs necessary for subsistence because the opportunity cost of purchasing price can double or triple the selling price. The risk of food insecurity is high and there is unlikelihood future for smallholders especially when agriculture labor force is poorly paid (Boussard, 1987 cited by Charlery de la Masselière, 1992; Ansoms, 2013). Maintenance of the certificate of land property is conditioned by the "rational use of land". Under penalty of being expropriated, the food function of agriculture has no longer priority over business interest. Agriculture operators do not just produce for themselves or their families. They must release a surplus for the market.

Since the 2004 land reforms policy, peasants and farmers are no longer self-employed workers. They have an account to provide of the use and assignment of the land they own. As the eminent land owner is the State, the boss is designated by land law as "the competent authority" (Organic Law on land tenure in Rwanda, 2005). Every agriculture landholder is not definitely landowner for free management of his property. In fact, although he has received the rights of exploitation materialized by a certificate of registration, rather a right of land property, he has a usufruct one. Thus, he is considered as any service provider to the State. Logically, he requires an adequate remuneration of his labor force or investments. In accordance with what is officially advocated in the 2004 Land Policy, land is a tradable commodity. It is no longer a common good for redistribution to landless population. Adequate remuneration for agricultural work may be an inherent perspective of the authority's obligations. But, the free market principles are not compatible with such regulation.

Promoting the agricultural food production function means valuing the farmer and giving him a role recognized by the community in the production of the country's wealth. Thus, it is in this sense that changes in agricultural policies must evolve, not only in market logic but also in social protection. "Peasant dignity" depends on it (Niyonkuru, 2017). It is not enough to reform the land to follow the guidelines of the donors concerning the modernization of the agricultural sector (Ndayishimiye, 2005). The agricultural sector in Rwanda has already reached its breaking point. There is no possibility of grabbing land because there is not enough area. Whoever occupies a certain agricultural area should be advised that someone else has been somehow ejected. That's why the owner is responsible for optimally exploiting the land he occupies for general interest. However, optimal exploitation requires that the land owner gets access to adequate income. Land grabbing would only aggravate the situation. It is necessary to reduce pressure on agricultural land where it is not in abundance. The diversification of economic activities is very urgent. The size of farms tends to decline over time and exclusive individual ownership of large farms is detrimental to the future of Rwandan agrarian systems. These observations are consistent with those of Burundi, a neighbouring country whose socioeconomic configuration and historical context are comparable (Ndayishimiye, 2005).

Therefore, it is necessary to enhance the status of family farming whose rights and duties change with land reforms in Rwanda. The recognition of the agricultural food function needs legal framework which establishes a social, legal and economic status of family farms. It should be noted that the property tax is mandatory for any landowner (Article 68) and the fact of 
enclosure land is not an act of rational management and sufficient conservation according to Articles 61 to 65 of the 2005 law land tenure system in Rwanda. This can be considered as a hoarding of agricultural land taken in the sense of a prolonged mobilization in time of a good by an individual who does not use it in productive way. Hoarding is denial to consume or invest in any form at all (Thuillier and Gaillard, 1965). However, one can ask the question if in fact a land not exploited according to the norms of the 2005 organic law on land tenure and the 2004 land policy reforms is automatically considered as non-productive use. In-depth research is required to refute or confirm if the land and agrarian reforms initiated by the Rwandan government in 2004 have contributed to rational use of rural lands. If so, is there any improvement in farmer access to local market as well as regional and international levels. The results of further research would also make it possible to evaluate if land sharing and regrouping of individual properties enables Rwandan peasant to improve land management. Have the land and agrarian reforms initiated by the Rwandan Government in 2004 improved the access to land ownership for peasant «Abahinzi » or investors "Abanyemari" in a balanced way? Has the redistribution and consolidation of individual land holdings helped to combat the non-productive use of rural land? The answers to these questions require further research that confronts the literature review with the realities on the field.

Furthermore, agrarian and land reforms must find a point of balance. The land reforms equilibrium may consist in reducing the pressure on the property assets by elites as well as it is improving the access to land and to inputs in favour of « market minded peasants » engaged in diversified food production (Allina-Pisano, 2004). Large-scale land in the context of land scarcity and growing population is a complex question. Therefore, the land sharing perspectives need large consultation and open debate. Large landowners could pay progressive taxes when their property size is beyond the marginal individual property. This marginal tax could be used to discourage land grabbing and facilitate the financing of economic projects initiated to avoid mass unemployment of dispossessed peasants in rural areas. Ali and Deininger (2015) have found an inverse relationship between farm size and productivity. The scale they used as small, medium and large farm is still open to discussion. Land consolidation has revealed that maize yield could be four times higher than the yield on fragmented land (Ekise et al., 2013). Property rights does not predict the rational land use nor for large neither for small, local or foreigner landowners in Rwandan rural economy. It is fundamental to perform sustainable assessments about the effects of individual property rights and collective use of land on agrarian system transformation in Rwanda.

Moreover, the possibilities of extending the territory beyond its borders as it used to be in the past are no longer exist (Nkusi, 2000). The perspectives of agrarian evolution in Rwanda are inherent in collective agriculture intensification to avoid excessive fragmentation for increasing production (Ekise et al., 2013, Musabanganji, 2016). Rwandan peasants have no more choice. They need to deal with the evidence of the scarcity of farm land and collaborate in the agriculture transformation. The capitalist approach adopted by the government is based on the principles of collective liberalism through commercial cooperatives (Gisaro, 2013). This political choice requires transformation of the land-man relationship under global economy. Obviously, farmers and peasants face a critical situation. Those who could be involved in other small and medium enterprises must not hesitate to ask for mentorship to Rwanda agriculture board (RAB, 2017; MINEACOM, 2017). They must find together with the government and the international partners who are coaching them the more sustainable solutions for their agrarian system transformation whereas prevent unemployment. How could smallholders take advantage of the market and minimize the risk of dispossession? The most vulnerable people live in rural areas. Almost 97\% have land and are raising livestock (National institute of statistics of Rwanda, 2015). The evidence of this research is that land in Rwanda is scarce and marginal individual property will continue to decrease over time in the high densely populated areas. Land sharing perspectives open a great debate on agrarian system transformation in Rwanda. 
Corresponding authors:

Mireille Mizero

Département d'Economie et du Développement rural, Gembloux Agro-Bio Tech

Université de Liège, Belgium

Phone: +32 465916053,E-mail:mireille.mizero@doct.uliege.be

\section{References}

[1] Ali, D. A and Deininger, K. (2015) "Is there a farm size productivity relationship in African Agriculture? Evidence from Rwanda", Land economics, Vol. 91, No. 2, pp. 317-343. E-ISSN 1543-8325, ISSN 0023-7639. DOI 10.1596/1813-9450-6770.

[2] Allina-Pisano, J. (2004) "Land reform and social origin of private farmers in Russia and Ukraine", The Journal of Peasant Studies, Vol. 31, Vol. 3, 4, pp. 489-514. DOI 10.1080/0306615042000262661.

[3] Amelot, X. (1997) "Pression démographique et dynamiques des systèmes ruraux au Rwanda", Cahiers d'outres-mer. Environnement et développement. Vol. 197, pp. 7-26. [On line] Available: http://www.persee.fr/doc/caoum_0373-5834_1997_num_50_197_3635. [Accessed: 7 May, 2018]. E-ISSN 1961-8603.

[4] André, C. (1998) "Terre rwandaise, accès, politique et réformes foncières", In: Marysse, S. (Dir.). Synergies. L'Afrique des Grands Lacs. Annuaire, pp. 141-173. ISSN 2258-4307.

[5] André, C. and Platteau, J. P. (1996) "Land tenure under unendurable stress: Rwanda in malthusian trap", Cahier de la Faculté des Sciences économiques et sociales, No. 164/7, Namur, Centre de Recherche en Economie du Développement, 49 p. [Online] Available https://repositories.lib. utexas.edu/bitstream/handle/2152/5453/2744.pdf?sequence=1\&isAllowed=y [Accessed: 6 Sept 2017].

[6] Ansoms, A. (2009) "Re-engineering rural society: the vision and ambitions of the Rwandan elite", African affairs, Vol. 108, No. 431, pp. 289-309. E-ISSN 1468-2621, ISSN 0001-9909. DOI 10.1093/afraf/adp001.

[7] Ansoms, A. (2010) "Views from below on the pro-poor growth challenge: The case of rural Rwanda", African Studies Review, Vol. 53, No. 2, pp. 97-123. E-ISSN 1555-2462, ISSN 0002-0206. DOI 10.1353/arw.2010.0037.

[8] Ansoms, A. (2013) "Large-scale land deals and local livelihoods in Rwanda: the bitter fruit of a new agrarian model", African Studies Review, Vol. 56, No. 3, pp. 1-23. E-ISSN 1555-2462, ISSN 0002-0206. DOI 10.1017/asr.2013.77.

[9] Ansoms, A., Verdoodt, A. and Van Ranst, E. (2008) "The Inverse Relationship between Farm Size and Productivity in Rural Rwanda", No. IOB Discussion papers (2008.9), 34 p.

[10] Burger, A. (2001) "Agricultural development and land concentration in a central European country a case study of Hungary", Land use policy, Vol. 18, No. 3, pp. 259-268. ISSN 0264-8377. DOI 10.1016/S0264-8377(01)00023-0.

[11] Charlery de La Masselière, B. (1994) "Versant du Rwanda: la gestion de l'incertitude" (in French), Les Cahier's d'outre-mer, Vol. 185, pp. 7-22. [Online] Available: http://www.persee.fr/doc/ caoum_0373-5834_1994_num_47_185_3501 [Accessed: 7 May 2018]. E-ISSN 1961-8603, ISSN 0373-5834.

[12] Compagnon, D. (2003) "La prétendue 'réforme agraire' au Zimbabwe. A qui profite le crime?" (in French), Études, Vol. 398, No. 3, pp. 297-307.

[13] Cousins, B. (2007) "More Than Socially Embedded: The Distinctive Character of 'Communal Tenure' Regimes in South Africa and its Implications for Land Policy", Journal of Agrarian Change, Vol. 7, No. 3, pp. 281-315. E-ISSN 1471-0366. DOI 10.1111/j.1471-0366.2007.00147.x. 
[14] Ekise, I. E., Nahayo, A., Mirukiro, J. D. and Mukamugema, B. (2013) "The impact of land use consolidation program on agricultural productivity: a case study of maize (Zea mays L.) production among households in Nyabihu district, Western Rwanda", Nature and Science, Vol. 11, No. 12, pp. 21-27. [Online] Available: http://www.sciencepub.net/nature [Accessed: 4 May 2018]. E-ISSN 2375-7167. ISSN 1545-0740.

[15] Fairbairn, M. (2013) "Indirect dispossession: domestic power imbalances and foreign access to land in Mozambique", Development and Change, Vol. 44, No. 2, pp. 335-356. E-ISSN 1467-7660. DOI 10.1111/dech.12013.

[16] Fond Monétaire International (2016) "Perspectives économiques mondiales: Afrique SubSaharienne, un changement de cap s'impose" (in French), Washington. ISBN 978-1-47551-544-2.

[17] Gisaro, C. Y. (2013) "La structuration du monde paysan au Rwanda: cas des coopératives et des stations de lavage de café de Maraba et de Karaba, district de Huye" (in French), Ph.D. Dissertation, Université de Gembloux agro-biotech.

[18] Herrera, A., Riddell, J. and Toselli, P. (1997) "Recent FAO experience in land reform and land tenure", Land Reform, Land Settlement and Cooperatives, Vol. 1, pp. 52-64. ISSN 0251-1894.

[19] Kalibata, A. (2018) "Re-envisioning investment for African Agriculture: top priorities for growing food, jobs and economies", Public Lecture, 23 March 2018, University of Liege, Belgium [Online]. Available: https://agra.org/wp-content/uploads/2018/03/University-of-Liege-Dr.-Kalibata-Speech. pdf [Accessed: 4 May 2018].

[20] Karangwa, A. (2008) "Diagnostique et essai de typologie des exploitations agricoles de Gikongoro (au Rwanda). Formulation et analyse socioéconomique des interventions de développement agricole" (in French), Ph.D. Dissertation, Université de Gembloux agro-biotech

[21] Kathiresan, A. (2012) "Land farm use consolidation in Rwanda: assessment from the perspectives of agriculture sector", Republic of Rwanda, Ministry of Agriculture and Animal Resources, Report.

[22] Klasen, S. and Reimers, M. (2014) "Looking at Pro-poor Growth from an Agricultural Perspective", Paper Prepared for the IARIW 33 rd General Conference Rotterdam, the Netherlands, August 24-30.

[23] Leegwater, M. E (2015) "Sharing scarcity: land access and social relations in Southeast Rwanda", PhD. Dissertation, Vrije Universiteit.

[24] Lenoir, R. (1984) "Le tiers monde peut se nourrir" (in French), Report of Club de Rome., Fayard, France. ISBN 2-213-01385-3.

[25] Maquet, J. J. (1967) "La tenure des terres dans l'État Rwanda traditionnel" (in French), Cahiers d'Études africaines, Vol. 7, No. 28, pp. 624-636. [Online] Available http:/www.persee.fr/ doc/cea_0008-0055_1967_num_7_28_3113. [Accessed: 07 May 2018]. E-ISSN 1777-5353, ISSN 00008-0055. DÖI 10.3406/cea.1967.3113.

[26] MINEACOM (2017) "Small industries that deals with agricultural products in Rwanda". [Online]. Available: https://www.youtube.com/watch?v=3B0btnKm-xs [Accessed: 10 May, 2018].

[27] Ministère des ressources naturelles (2018) Arrêté ministériel $n^{\circ}$ 002/2008 du 01/04/2008 portant modalités d'enregistrement des terres. République du Rwanda (in French).

[28] Ministère des terres, de l'environnement, des forêts, de l'eau et des mines (2004) "Politique Nationale foncière. Républiques du Rwanda". [Online]. Available: http://www.amis.minagri.gov.rw/ $\mathrm{fr} /$ documents/projet-de-politique-nationale-fonciere [Accessed: $10 \mathrm{May}, 2018$ ].

[29] Musabanganji, E., Karangwa, A. and Lebailly, P. (2016) "Intensification of smallholder agriculture in Rwanda: Scenarios and challenges toward a sustainable transformation", $5^{\text {th }}$ international conference on $A A A E$, United Nations Conference Center: Transforming smallholder agriculture in Africa, the role of policy and governance, 23-25 September, Addis Ababa Ethiopia.

[30] National Institute of Statistics of Rwanda (NISR) Ministry of Finance and Economic Planning (MINECOFIN) (2012) "Rwanda Fourth Population and Housing Census", Thematic Report: Population size, structure and distribution. 
[31] National Institute of Statistics of Rwanda (NISR) (2015) "Social protection and VUP Report, 2013/14". [Online]. Available: http://www.statistics.gov.rw/publication/rwanda-social-protectionand-vup-report-results-eicv-4 [Accessed: 5 May 2018].

[32] Ndayishimiye, P. (2005) "Relations cultures vivrières-cultures de rente et dynamiques agraires au Burundi: une étude de cas à partir de trois régions agro-écologiques (Buyenzi, Imbo-sud et Mugamba-sud)" (in French), Ph.D. Dissertation, Université de Liège, Faculté universitaire des sciences agronomiques de Gembloux.

[33] Niyonkuru, D. (2018) "Pour la dignité paysanne : expériences et témoignages d'Afrique, réflexions, pistes méthodologiques" (in French), Groupe de recherche et d'information sur la paix et la sécurité. Brussels, Belgium. ISBN 978-2-87291-115-8.

[34] Nkusi, J. (2000) "Problématique du régime foncier au Rwanda: contexte et perspective, relation avec l'habitat regroupé" (in French). Report of consultancy. [Online]. Available: https://repositories. lib.utexas.edu/bitstream/handle/2152/5932/3185.pdf?sequence=1\&isAllowed $=\mathrm{y}$ 10 May 2018].

[35] UrbanLex (2005) "Organic Law 08/2005, 14/07/2005 governing land tenure in Rwanda". [Online]. Available: http://urbanlex.unhabitat.org/law/194 [Accessed: 9 May, 2018].

[36] RAB (2017) "Rwanda agriculture board RAB activites" [Online] Available: https://www.youtube. com/watch?v=JGhPwDlcJZ0 [Accessed: 10 May, 2018].

[37] Radio Itahuka (2018) "Radio Itahuka Kuri Sw 19M 15420 Khz: Micombero \& Mukombozi Barasubiza Ibibazo Twandikiwe". [Online]. Available: https://www.youtube.com/watch?v=Ae_uwYc4oBQ [Accessed: 6 May 2018].

[38] Republic of Rwanda, Natural Resources Authority (2016) "Ugusaranganya ubutaka". [Online]. Available: https://www.youtube.com/watch?v=CXnpRkwv2Hk [Accessed: 30 April 2018].

[39] République du Rwanda, Ministère de l'agriculture et de l'Elevage (2004) "Plan stratégique pour la transformation de l'Agriculture au Rwanda" (in French). Main document. [Online]. Available: http://www.amis.minagri.gov.rw/fr/documents/plan-strategique-pour-la-transformation-de1\%E2\%80\%99agriculture-au-rwanda [Accessed: 6 May 2018].

[40] République du Rwanda, Ministère des terres, de l'environnement, des forêts, de l'eau et des mines (2004), "Politique Nationale foncière". [Online]. Available: http://www.amis.minagri.gov.rw/fr/ documents/projet-de-politique-nationale-fonciere [Accessed: 15 May, 2018].

[41] Rwanda TV (2018) "Umwiherero w'Abayobozi b'inzego $z^{\prime}$ 'ibanze", Kigali, Petit stade, $28^{\text {th }}-29^{\text {th }}$ March [Online]. Available: https://www.youtube.com/watch?v=OjErl6McXxY [Accessed: 4 May 2018]

[42] Skrubbeltrang, F. (1953) "Agricultural development and rural reform in Denmark", Food And Agriculture Organization Of The United Nations: Rome, p. 320.

[43] Thuillier, G. and Gaillard, Y. (1965) "Sur la thésaurisation" (in French), Revue économique, Vol. 16, No. 5, pp. 796-808. [Online]. Available: http://www.persee.fr/doc/reco_0035-2764_1965_ num_16_5_407681 [Accessed: 7 May 2018].

[44] Van Hoyweghen, S. (1999) "The urgency of agrarian and land reform in Rwanda", African affairs, Vol. 98, No. 392, pp. 353-372. E-ISSN 1468-2621, ISSN 0001-9909. DOI 10.1093/oxfordjournals.afraf.a008044.

[45] Verwimp, P. (2011) "The 1990-92 massacres in Rwanda: A case of spatial and social engineering?", Journal of Agrarian Change. Vol. 11, No. 3, pp. 396-419. E-ISSN 1471-0366. DOI 10.1111/j.1471-0366.2011.00315.x. 